\title{
KEPERCAYAAN DIRI REMAJA
}

Oleh : Jubliana Anthoneta Ratu $\mathrm{Pa}^{1}$

\begin{abstract}
Adolescence is a critical period of someone's phsycological developments. In this stage, self actualization is one of important areas are developing. It is formed by various different factors that are combined together to build a teenager's prespective of their self or their environtment around them. One of crusial elements in self actualization is confidence. It will take significant effect in the next stage of teenager's development.
\end{abstract}

Key words : adolescence, confidence, phsycology, teen, teenager

\section{Pendahuluan}

Percaya Diri atau kepercayaan diri sangat diperlukan oleh setiap orang, khusus pada usia remaja. Hal ini disebabkan karena dalam masa ini remaja sedang berada dalam proses pencarian jati diri, dan juga pada usia ini remaja juga sedang berusaha untuk mendapatkan atau menemukan banyak teman, sehingga ini penting. Tetapi seringkali pada masa ini juga anak remaja sulit untuk membangun kepercayaan diri.

Oleh karena itu, pada bagian ini akan dibahas mengenai pengertian kepercayaan diri, unsur-unsur pembentuk kepercayaan diri, dan wujud nyata kepercayaan diri. Semuanya akan dibahas dengan lengkap sebagai berikut:

\section{Pengertian Kepercayaan Diri}

Kepercayaan diri secara sederhana dapat diartikan sebagai keyakinan yang akan kemampuan atau kelebihan diri sendiri (yang unik dan berpotensi), yang dapat dimaksimalkan untuk mencapai harapan maupun tujuannya. Pada umumnya kepercayaan diri dimengerti sebagai keyakinan seseorang akan kemampuannya untuk melakukan hal-hal tertentu. Artinya, keyakinan dan percaya diri hanya timbul pada saat seseorang mengerjakan sesuatu yang memang mampu dilakukannya.

Secara konseptual, percaya diri sebagi tekad seseorang pada diri sendiri yang bersumber dari hati nurani untukk melakukan segala sesuatu yang diinginkan dan dibutuhkan dalam hidup. Definisi operasional, percaya diri adalah, tekad seseorang pada dirinya sendiri yang bersumber dari hati nurani untuk melakukan segala sesuatu yang diinginkan dan dibutuhkan. ${ }^{2}$

\footnotetext{
${ }^{1}$ Jubliana Anthoneta Ratu Pa adalah dosen program studi Pendidikan Agama Kristen di STTNI Yogyakarta. Menyelesaikan program Sarjana Teologi di STTII Yogyakarta dan mendapatkan gelar M. Pd.K. dari STT Kadesi Yogyakarta.

2 Jason Lase, Motivasi Berprestasi Kecerdasan Emosional, Percaya Diri dan Kinerja, (Jakarta: Program Pasca Sarjana UKU, 2005), 112.
} 
Kepercayaan diri adalah sikap positif seorang individu yang memampukan dirinya untuk mengembankan penilaian positif baik terhadap diri sendiri maupun terhadap lingkungan atau situasi yang dihadapinya.

Kepercayaan diri berawal dari tekad pada diri sendiri, untuk melakukan segala yang diinginkan dan dibutuhkan dalam hidup. Percaya diri berbina dari keyakinan diri sendiri, bukan dari karya-karya, walaupun karya-karya itu sukses. Rasa percaya diri itu lahir dari kesadaran bahwa ketika seseorang memutuskan untuk melakukan sesuatu, sesuatu itu pula yang akan dia lakukan. ${ }^{3}$

Hal ini bukan berarti bahwa individu tersebut mampu dan kompeten melakukan segala sesuatu seorang diri, alias "sakti”. Sementara De Angelis dalam bukunya Percaya Diri membagi konsep kepercayaan diri menjadi tiga (3) jenis yaitu:

Pertama, kepercayaan diri dalam tingkah laku, adalah kepercayaan diri yang dimiliki seseorang untuk melakukan apapun yang diinginkan secara maksimal. Kedua, kepercayaan diri emosional, adalah keyakinan yang dimiliki oleh seseorang untuk menguasai diri. Ketiga, kepercayaan diri spiritual adalah keyakinan yang dimiliki seseorang dalam hubungannya dengan keberadaan seluruh alam semesta ini. $^{4}$

Untuk lebih memperjelas pembahasan mengenai Kepercayaan Diri, maka dalam bagaian ini akan membahas tentang Kepercayaan Diri itu sendiri, dalam arti pengertian istilahnya. Kepercayaan menurut Kamus Bahasa Indonesia yaitu: Anggapan (keyakinan) bahwa benar, sesuatu yang dipercayai, harapan dan keyakinan (akan kejujuran, kebaikan, dan lain sebagainya). ${ }^{5}$

Sementara menurut Kamus Besar Bahasa Indonesiamenjelaskan bahwa keyakinan berasal dari kata "percaya" yang berarti: yakin benar atau memastikan akan kemampuan atau kelebihan seseorang atau sesuatu (bahwa akan dapat memenuhi harapannya dan sebaginya) kepada diri sendiri. ${ }^{6}$

Terdapat satu hal yang berkaitan erat dengan kepercayaan diri, yakni konsep diri. Konsep " diri (Self)" merupakan suatu bagian yang penting dalam setiap pembicaraan tentang kepribadian yang sehat. Baik kata maupun konsep tersebut kelihatannya sederhana, tetapi banyak ahli psikologi yang mencoba memberi penjelasan atau teori tentang arti dari istilah yang sederhana ini.

\footnotetext{
${ }^{3}$ Ibid, 93 .

${ }^{4}$ De Angelis Barbara, Percaya Diri pen. Baty Subakti (Jakarta: PT SUN, 1995), 58.

${ }^{5}$ W.J.S.Poerwadarminto, “Anggapan”, dalam Kamus Umum Bahasa Indonesia (Jakarta: Balai Pustaka, 1982), 737.

${ }^{6}$ Tim penyusun Kamus Besar Bahasa Indonesia, "Percaya” dalam kamus besar Bahasa Indonesia, Peny. AntonM. Moeliono (Jakarta: Balai Pustaka, 1993), 669.
} 
Allport ingin membedakan konsep "diri" dengan menggunakan istilah "proprium". Proprium menunjukkan keapda sesuatu yang dimiliki seseorang atau unik bagi seseorang. Itu berarti proprium (atau self) terdiri dari hal-hal atau proses-proses yang penting dan bersifat pribadi bagi seorang individu, segi-segi yang menentukan seseorang sebagai yang unik. ${ }^{7}$

\section{Unsur-unsur dari Kepercayaan Diri}

Sebenarnya kebutuhan-kebutuhan dasar seseorang tidak terlalu berubah dari masa kecil sampai tua. Kalau kebutuhan-kebutuhan dasar atau hakiki seorang anak belum terpenuhi di bawah usia lima dan dua belas tahun, maka akan berbekas dalam kesulitankesulitan dan sikap kurang wajar ketika orang itu beranjak dewasa.

Kebutuhan-kebutuhan anak yang paling mendasar ialah: pertama, harga diri, atas dasar yang wajar. Kedua, pengenalan diri (identitas). Ketiga, disiplin diri atau ketertiban. Keempat, pengorbanan diri demi orang lain. ${ }^{8}$

Sejak usia dini sampai 11 atau 12 tahun, orang yang diteladani oleh anak adalah orang tua sendiri. Bila orang yang dipilih mempunyai karakter dan kepribadian yang baik, itu tidak akan menjadi masalah. Namun jika orang yang dipilih itu mempunyai tabiat atau perilaku yang buruk, misalnya pecandu narkotik, akibatnya mungkin sesuatu yang tidak diinginkan. ${ }^{9}$

Apabila anak itu memasuki usai kurang lebih 13-14 tahun maka dalam menghadapi segala kegelisahan masa remajanya, melepaskan diri dari orang tua dan para sesepuhnya dan mulai dengan komunitasnya yang baru yaitu teman-temannya. Sampai pada awal kedewasaan teman-temannyalah yang banyak berpengaruh dalam pengambilan keputusan.

Konsep diri adalah bagaimana seseorang menggambarkan diri dan self esteem adalah evaluasi dari gambaran tersebut. Identitas itu bertumbuh. Seseorang mulai mengenal siapa dirinya dan akan menjadi apa dirinya. Di dalam setiap tahapan dalam hidupnya, self esteem selalu akan berubah dan berkembang. Seseorang akan menjadi lebih teguh ketika identitasnya bertumbuh.Jika seseorang memiliki konsep diri yang positif (bila menyukai apa yang mereka lihat tentang dirinya), dapat dikatakan bahwa orang tersebut memiliki self esteem yang tinggi.

Terdapat tiga (3) unsur yang terkait dalam pembentukan kepercayaan diri, atau dapat dikatakan bahwa ketiga hal ini tidak dapat dipisahkan dari penilaian terhadap kepercayaan diri. Hal tersebut ialah:

${ }^{7}$ G. Allport, Becoming: Basic Consideration for a Psychology of Personality (New Heaven: Yale University Press, 1995), 25.

${ }^{8}$ Stanley Heath: Kumpulan Makalah Lepas (Bandung: Institut Alkitab Tiranus, 1995), 174

${ }^{9}$ Adi W. Gunawan: Genius Learning Strategy: Petunjuk Praktis untuk menerapkan Acclerated Learning (Jakarta: Gramedia Pustaka Utama, 2003), 20. 
Self - Worth. Nilai diri adalah perasaan seseorang tentang hal yang layak diperoleh di dalam hidupnya. Ia menyadari bahwa ia layak untuk bergembira dan ia menetapkan sasaran untuk mengerjakan hal-hal dalam meraih kegembiraan.Self Confidence. Percaya diri adalah memiliki motivasi dan kecenderungan untuk berhasil dalam hidup. Seorang anak tidak hanya ingin berhasil, tetapi juga harus memiliki kemauan dan inisiatif untuk merealisasikan keberhasilan tersebut.Self Acceptance. Penerimaan diri adalah perasaan puas terhadap kehidupan seseorang sama dengan puas terhadap diri sendiri. ${ }^{10}$

\section{Faktor-faktor yang Mempengaruhi Terbentuknya Kepercayaan Diri}

Dalam upaya pembentukan kepercayan diri seorang anak remaja, ada begitu banyak faktor yang mempengaruhi, diantaranya yaitu: faktor keluarga dan lingkungan. Kedua faktor ini inilah yang paling dominan dalam pembentukan kepercayaan diri anak remaja. Karena pada masa remaja adalah masa dimana seorang anak telah tumbuh dari segi kognitif sudah dapat memilih dan menggunakan daya nalarnya untuk mengakomodasi apa yang dipikirkan dan yang diinginkannya.

Pada usia ini (11 tahun sampai 15 tahun) anak merasa bahwa mereka bukan lagi sebagai anak-anak tapi juga mereka bukanlah orang dewasa, atau dengan kata lain mereka disebut sebagai anak yang sementara mencari jati diri yang sesungguhnya.

Remaja merupakan masa pembentukan perasaan mengenai identitas diri. Identitas mencakup cara hidup pribadi yang dialami sendiri dan sulit dikenal orang lain. Secara hakiki ia tetap sama walaupun telah mengalami berbagai macam perubahan. Masa remaja merupakan masa dimana ketakutan dan emosionalitas yang tidak stabil adalah yang hal normal. Masa remaja dalam tinjauannya lebih memperhatikan pengaruh faktor lingkungan sosial, dibandingkan dengan faktor biologi dan tingkah laku seksual. ${ }^{11}$

Anak terbentuk sesuai dengan apa yang diajarkan, baik itu dalam lingkungan keluarga maupun sekolah. Itulah sebabanya pengenalan diri ini sangat perlu untuk dapat bergaul. Dalam pergaulan selalu ada respons tertentu yang diharapkan. Kalau pengenalan diri seseorang keliru, ia akan menyapa dan menilai diri sendiri sangat rendah. ${ }^{12}$

Sebisa mungkin orang tua memberikan reward atau penghargaan kepda anak atas berbagai prestasi yang dilakukan. Sebaliknya, sedapat mungkin menghindari bentuk punishment atau hukuman. Karena hukuman yang kelewat akan membuat harga diri anak down atau turun.

\footnotetext{
${ }^{10}$ Lase, Motivasi Berprestasi Kecerdasan Emosional, 96.

${ }^{11}$ Jason Lase; Pengaruh Lingkungan Keluarga dan Sekolah terhadap Vandalisme Siswa (Jakarta: Pasca Sarjana UKI, 2005), 99.

${ }^{12}$ Jacinta Rini: Percaya Diri, 110.
} 
Afirmasi yang diberikan oleh orang tua adalah merupakan tindakan kognisi internal yang menetapkan suatu logika spesifik, arah, hasil atau keadaan yang diinginkan di masa depan. Afirmasi sebagai suatu alat, merupakan penyataan tertulis atau deklarasi mental tentang bagaimana anak akan menjalani hidup. ${ }^{13}$

Dalam hal prestasi anak, seringkali orang tua kurang memperhatikan hubungan antara kepercayaan diri dan konsep diri dalam kaitannya dengan proses pembelajaran $\mathrm{s}$ anak. Menurut Dhanang:

Dasar untuk mendorong minat belajar anak, kita perlu meningkatkan rasa percaya diri anak. Karena prinsip dasar anak belajar haruslah menyenangkan. Karena menyenangkan akan menumbuhkan emosional yang positif. Dalam proses belajar, anak harus diposisikan sebagai subjek dan bukan objek. ${ }^{14}$

Rasa percaya diri yang tinggi sebenarnya hanya merujuk pada adanya beberapa aspek drai kehidupan individu tersebut dimana ia merasa memiliki kompetensi, yakin, mampu dan percaya bahwa ia bisa karena didukung oleh pengalaman, potensi actual, prestasi serta harapan yang realistic terhadap diri sendiri.

Seorang anak yang terkembang akan semakin mandiri karena orang tuannya memberikan kesempatan untuk memperoleh pangalaman hidup. Segera setelah si anak dipandang mampu melakukan sesuatu yang biasa dikerjakan orang tua untuknya, orang tua mengijinkannya melakukan sendiri.

Faktor Harga Diri dan Konsep Diri secara umum

Sebagaimana dikatakan di atas bahwa percaya diri sangat dekat hubungannya dengan harga diri, dan konsep diri. Oleh karena akan dibahas kedua pokok tersebut.

\section{Harga Diri}

Harga Diri (self esteem) ialah dimensi evaluatif global dari diri. Harga diri juga diacu sebagai nialai diri atau citra diri. Konsep diri (self concept), mengacu pada evaluasi bidang spesifik dari diri sendiri. Anak-anak dapat membuat evaluasi diri dalam banyak bidang kehidupan mereka: akademis, atletik, penampilan, dan lain-lain. Secara ringkas

\footnotetext{
${ }^{13}$ Tengku Asmadi: “Mendidik Anak Tinggi EQ”, Ayah Bunda, September 2007.

${ }^{14}$ Dhanag Sasongko, "Meningkatkan Minat Belajar," Harian Seputar Indonesia, 21 Februari 2007.
} 
harga diri mengacu pada evaluasi diri yang bersifat global sedangkan, konsep diri mengacu kepada evaluasi bidang lebih spesifik. ${ }^{15}$

Komponen bagi terbentuknya keprcayaan diri seseorang adalah: harga diri dan konsep diri yang benar. Harga diri merupakan komponen yang bersifat emosional dan merupakan komponen yang paling penting dalam menentukan sikap dan kepribadian seseorang. Harga diri merupakan kunci untuk mencapai keberhasilan hidup. ${ }^{16}$ Harga diri didefinisikan sebagai kecenderungan untuk memandang diri sendiri sebagai pribadi yang mampu dan memiliki daya upaya dalam menghadapi tantangan-tantangan hidup yang mendasar dan layak untuk hidup bahagia. ${ }^{17}$

Konsep harga diri yang benar akan membentuk seseorang menjadi orang yang bis menghargai diri sendiri dan orang lain. Orang cenderung untuk kurang menghargai diri sendiri oleh karena ia memiliki penilaian yang salah terhadap diri sendiri dan juga orang lain. Anak yang kurang memiliki rasa percaya diri, biasanya memiliki pandangan lain terhadap diri anak. ${ }^{18}$

Dalam tahap perkembangan anak dapat dilihat tingkat-tingkat pemahaman terhadap diri sendiri. Tingkat pertama, anak akan mencoba melihat siapa dirinya (self) dalam artian perkembangan dirinya sejak bagi sampai ia bisa melihat perbedaan dengan jelas diri jasmaninya, (misalnya ia bisa membedakan antara tangan dan kaki, mata dan telinga dan lain sebagainya).

Pada tingkat kedua dari suatu perkembangan, muncullah perasaan identitas yang terpisah. Sedangkan pada atingkat yang ketiga, ialah munculnya harga diri. Inti dari munculnya harga diri ialah kebutuhan anak akan otonomi. Pada tahap ini merupakan tingkat perkembangan yang menentukan, apabila orang tua menghalangi kebutuhan anak untuk menyelidiki maka perasaan harga diri yang timbul dapat dirusakkan. Akibatnya dapat timbul perasaan hina dan marah. ${ }^{19}$

Konsep diri berhubungan erat dengan kesadaran diri atau biasa disebut juga dengan gambar diri. Gambar diri dapat dilihat dari bagaimana seorang anak memandang dirinya.Kesadaran diri seseorang akan tumbuh bila ia bekerja selaras dengan "diri" sendiri. Dalam menghadapi perkembangan ini maka, haruslah diperhatikan bagamana anak melihat dunia di sekitarnya. Dengan mengevaluasi efektifitas dalam pengendalaian kehidupan sendiri, memahami hakikat diri sendiri dan mengetahui jalan pikiran sendiri, memungkikan seseorang lebih terbuka untuk belajar dan berkembang. ${ }^{20}$

"Gambar Diri”, jika didefinisikan maka, citra atau gambar diri adalah gambaran kita terhadap diri sendiri atau pikirain kita tentang pandangan orang lain terhadap diri

\footnotetext{
${ }^{15}$ Jhon W. Santrock, Life - Span Development: Perkembangan Masa hidup, Jil., I pen. University of Texas at Dasllas (Jakarta: Erlangga, t,.t.). 356.

${ }^{16}$ Gunawan: Genius Learning Strategy, 15.

${ }^{17}$ Ibid, 22

${ }^{18}$ Elia Daryaty, R. "Pedagagogi dan Psikologi”. Haraian Pikiran Rakyat, 5 Agustus 2007.

${ }^{19}$ Duane Schultz: PsikologiPertumbuhan: Model-model Kepribadian yang sehat (Yogkarta: Kanisisus, 1991), 27.

${ }^{20}$ Patricia Patton, EQ Kecerdasan Emosional: Membangun Hubungan (Jakarta: Pustaka Delaprasta, 1998), 31.
} 
kita. ${ }^{21}$ Harga diri atau citra diri adalah karakeristik intelegensi emosii yang menunjukkan penilaian diri dan merupakan sumber penting bagi rasa percaya diri. Ini berarti memiliki perasaan-perasaan yang sesuai, perasaan yang baik tentang siapa dirinya sebagai pribadi. Merasa puas dengan diri sendiri.

Harga diri positf adalah suatu kualitas yang menggaris bawahi pengembangan batiniah yang dapat mengantarkan kita menuju penghargaan diri dan kesuksesan pribadi. Harga diri merupakan katalisator untuk mempertahankan cahaya batin dan akan menciptakan kondisi lingkungan eksternal yang kondusif bagi pengembangan diri. Harga diri adalah penghargaan terhadap keunikan penampilan fisik, kemampuan-kemampuan intelektual, kecakapan pribadi, dan kepribadian. ${ }^{22}$

Harga diri ini berkaitan dengan dua hal yaitu:perasaannya kompetensi pribadi dan perasaan nilai pribadi,atau dengan kata lain harga diri itu merupakan perpaduan antara kepercayaan diri dan penghormatan diri. Jadi jika berbicara mengenai kepercayaan diri itu tidak terlepas dari apa yang disebut dengan "harga diri" Mempunyai harga diri yang kuat artinya cocok dengan kehidupan dan penuh keyakinan, yaitu mempunyai kompetensi dan sanggup mengatasi masalah-masalah kehidupan. Seorang anak yang tumbuh siap untuk mengambil resiko, belajara terampil menghadapi situasi baru. Termasuk menghadapi resiko kegagalan dan kekecewaan. Kepercayaan dan dorongan yang lembut dari orang tua akan memberikan hasil yang berbeda. Kadangkala orang tua perlu member dorongan kepercayaan dan pengharapan karena anak sendiri kurang percaya diri dan kurang pengharapan. ${ }^{23}$

Harga diri itu sendiri mengandung arti suatu hasil penilaian individu terhadap dirinya yang diungkapkan dalam sikap-sikap yang dapat bersifat positif dan negatif. Bagaimana seseorang menilai dirinya akan mempengaruhi perilaku kehidupannya sehari-hari. Cara seseorang memandang diri sendiri sangat berperan dalam menentukan citra diri macam apa yang diciptakannay dan dapat membuat perbedaan dengan cara pandang orang lain terhadap diri kita. Jika yakin bahwa dirinya berharga dan bernilai, maka caranya membawa diri, keputusan yang dibuat, dan juga harapan-harapannya akan mencerminkan perspektif internal dan orang lain pun akan cenderung melihat dia dengan cara yang sama.

Pengenalan diri yang memadai menuntut pemahaman tentang hubungan atau perbedaan antara gambaran tentang diri yang dimiliki seseorang dengan dirinya menurut keadaan yang sesungguhnya. Semakin dekat hubungan antara kedua gagasan ini, maka individu juga semakin matang. Orang yang memiliki suatu tingkat pemahaman diri (sel objectification) yang tinggi atau wawasan diri tidak mungkin memproyeksikan kualitas-kualitas pribadinya yang negative kepada orang

\footnotetext{
${ }^{21}$ Valentino Hadiwibowo,: "Gambar diri ," Sinar Harapan sore, 17.

${ }^{22}$ Patricia Patton, Landasan Untuk Meraih Sukses Pribadi dan Karier (Jakarta: Mitra Media, 1998),
} 94.

\footnotetext{
${ }^{23}$ Wanda Humble, Diktat Kuliah "Psikologi Perkembangan" (STTII Yogyakarta; 1992)
} 
lain. Biasanya orang yang memiliki wawasan diri yang lebih baik adalah lebih cerdas daripada orang yang memiliki wawasan diri yang kurang. ${ }^{24}$

Cara seorang anak memandang diri sendiri adalah sumber mental yang dapat dikembangkan dan diubah sesuai pilihannya. Untuk bisa membangun harga diri anak atau citra diri anak yang benar maka: Pertama, anak harus diajar untuk dapat menerima diri sendiri apa adanya. Anak rendah diri memerlukan pemahaman orang tua. Orang yang paling dekat dalam pembentukan kepribadian anak adalah orang tua, caranya adalah dengan mengenali kemampuan anak dan menghargainya, sebagai pribadi, bukan sebagai objek yang harus memenuhi tuntutan semata.

Kedua, anak didorong untuk memiliki sikap kemandirian dan ada baiknya memiliki suatu ketrampilan tertentu yang menjadi bagian penting untukk meningkatkan rasa percaya diri. Rasa mampu pada anak akan menjadi indikasi positif bagi anak untuk mengembangkan diri selanjutnya dan anak akan lebih mudah untuk menghargai diri sendiri.

Ketiga, hal yang terpenting yang harus dimiliki oleh orang tua adalah dengan menujukkan sikap peduli. Sebelum anak mampu menerima diri sendiri apa adanya, orang tua harus terlebih dahulu menerima diri anak apa adanya.

Istilah "harga diri" banyak digunakan untuk menerangkan sikap dan tingkah laku terhadap diri sendiri, maupun orang lain. Kata-kata seperti kepercayaan diri, penghargaan diri, dan cinta diri menjelaskan bagaimana seseorang memandang dirinya sendiri. Orang dengan harga diri yang rendah otomatis melumpuhkan potensinya. Harga diri yang rendah juga akan merusak mimpi-mimpi seseorang. Orang dengan harga diri yang rendah juga akan menghambat hubungannya dengan orang lain.

\section{Konsep Diri}

Seringkali orang memandang konsep dirinya dari apa yang dihasilkan, dan bukan pada prosesnya sehingga apabila ia tidak berhasil maka, hilang konsep dirinya yang benar itu. Konsep diri itu terbentuk melalui suatu proses, bukan faktor keturunan, atau bawaan lahir atau berhasil tidaknya ia mengerjakan sesuatu. Konsep diri akan terbentuk sejalan dengan pertumbuhan dan perkembangannya melalui interaksi dengan orang tua, keluarga dan lingkungan di sekitarnya. Saat anak masuk sekolah maka, interaksi dengan teman di sekolah, guru dan lingkungan sekolah turut berperan dalam pembentukan konsep diri.

Konsep diri dapat terbentuk melalui: Pertama, diperoleh melalui proses pemberlajaran dan bukan faktor keturunan. Kedua, diperkuat melalui pengalaman hidup yang dialami setiap hari. Ketiga, dapat berubah secara dramatis. Keempat, mempengaruhi proses pembelajaran dan prestasi. Kelima, mempengaruhi proses berpikir dan berperilaku.

\footnotetext{
${ }^{24}$ Schultz, Psikologi Pertumbuhan, 34
} 
Keenam, dapat dibangun dan dikembangkan denganmengganti sistem keprcayaan yang merugikan dan mengganti self talk yang negative dengan positif.

Bila konsep diri yang buruk ini terdapat dalam diri seorang guru atau orang tua maka, ini akan sampai kepada murid atau anak, baik melalui komunikasi sadar dan komunikasi di bawah sadar. ${ }^{25}$

\section{Faktor Keluarga}

Salah satu faktor yang mempengaruhi perkembangan kepercayaan diri adalah hubungannya dengan orang lain terutama 'significant other's seperti orang tua, saudar kandung, dan teman-teman dekat. Keluarga adalah oang terdekat yang banyak sekali memberikan kontribusi bagi terbentuknya kepercayaan diri seorang anak.

Pengertian keluarga dalam arti luas adalah ikatan yang meliputi semua pihak yang ada hubungan darah, atau yang disebut dengan clan atau marga. Sedangkan dalam arti sempit, adalah hubungan darah, antara keluarga inti yang terdiri atas ayah ibu dan anak. ${ }^{26}$ Adalah sangat penting untuk mengerti fase perkembangan intelektual anak dari fase satu ke fase yang lainnya. Faktor yang paling dominan adalah tingkat kematangan emosional yang dia terima.

Orang tua haruslah benar untukk mengajarkan remaja untuk menjelaskan secara benar dan akurat apa yang ada dalam pikirannya. Orang tua haruslah lebih sabar dan mengasihi anak-anak sulit dan untuk mengajarkan para remaja untukdapat berpikir secara jernih. $^{27}$

\section{Penerimaan dalam Keluarga}

Faktor-faktor seperti penerimaan orang ut dan pemberian kebebasan kepada anakanak dalam batas-batas yang ditentukan denganjelas kemungkinan merupakan faktor-faktor penting yang menentukan harga diri anak. ${ }^{28}$ Dalam keluarga, peranan orang tua sangat penting dalam membentuk pribadi anak. Perlakuan orang tua dalam mengasuh anak sangat menentukan perilaku anak menjadi perilaku yang pro sosial atau anti sosial. Meskipun banyak faktor yang mempengaruhi kepercayaan diri seseorang, namun faktor pola asuh dan interaksi di usia dini merupakan faktor yang amat mendasar bagi pembentukan rasa percaya diri anak. Dalam lingkungan keluarga, peranan orang tua sangat dominan.

\footnotetext{
${ }^{25}$ Gunawan, Genius Learning Strategy, 24

${ }^{26}$ Jason Lase, Pengaruh Lingkungan Keluarga, 35

${ }^{27}$ D. Ross Campbell, How to Really Love Your Teenager (Illinois: Victor Books SP, Publications, 1983), 25

${ }^{28}$ Santrock, Life-Span Development: Perkembangan Masa Hidup, jil. I (Jakarta: Erlangga Publications, 1983), 25
} 
Orang tua sebaiknya juga mendorong anak untuk berani keluar dan menghadapi dunia luar dengan penuh percaya diri. Terakhir orang tua sedapt mungkin mengetahui kesukaan dan potensi anak, serta mendorongnya untuk berani melakukan hal-hal tertentu lewat media hobi dan potensi dirinya. ${ }^{29}$

Sikap orang tua adalah hal yang paling penting bagi perasaan seseorang, khususnya pada masa-masa awal tahun hidupnya. Ketika orang tua menyediakan penerimaan, maka seseorang menerima sebuah dasar yang kuat tentang perasaan yang baik bagi dirinya. Jika orang tua terlalu melindungi dan menghalangi independensi seseorang, maka orang tersebut telah menerima suatu nilai tentang penerimaan dan cinta, juga orang tersebut dapat belajar untuk menerima dirinya dan dia sedang berada di jalan pengembangan kepercayaan diri.

Pada hakekatnya orang tua bertanggung jawab untuk memelihara, melindungi, dan mendidik. Suasana hubungan di dalam keluarga dapat menciptakan suasana hangat dan keakraban serta memupuk tumbuhnya rasa aman dan percaya bagi diri remaja. Sebaliknya tanpa kehangatan dan keakraban dalam keluarga dapat menjadikan remaja cemas dan tidak percaya diri. Tanpa kemesraan dan kasih sayang dari orang tua, remaja kurang mampu menjalin hubungan yang berarti dengan orang lain. ${ }^{30}$

Bagaimana cara keluarga mempelakukan anak sejak kecil akan membawa dampak yang besar bagi pengembangan kepribadian maupun karakter anak. Jika dalam keluarga anak terbiasa diberi penghargaan sesuai dengan apa yang dia kerjakan, maka anak akan tumbuh menjadi anak yang penuh percaya diri. Tetapi jika anak tumbuh dalam keluarga yang tidak pernah member penghargaan atau selalu member penghukuman dan hinaan, maka anak akan tumbuh menjadi anak yang rendah diri.

Perasaan dikasihi ini merupakan perasaan untuk diingini, diterima, diperhatikan, disenangi, dan dikasihi. Jikalau seseorang merasa tidak diingini kehadirannya, ia akan jarang memiliki perasaan dimiliki. Demikian selanjutnya kurangnya perasaan untuk diingini menjadikan perasaan kurang dikasihi. Perasaan ini akan muncul pertama-tama dari dalam keluarga asal ataupun keluarga yang membesarkan seseorang.

\section{Afirmasi dalam Keluarga}

Afirmasi bukanlah sekedar ucapan klise yang diucapkan orang tua kepada anak sebagai formalitas saja, tetapi afirmasi dibutuhkan oleh seorang anak untuk dapat mendorong si anak untuk melihat sisi positif yang dimilikinya dan hal itu dapat mengembangkan konsep kepercayaan dirinya.

\footnotetext{
${ }^{29}$ Martina Rini. S Tasmin, "Peranan Keluarga dalam Pembentukan Harga Diri," (WWW.Kepercayaan Diri Anak.com)

${ }^{30}$ Jason Lase, Pengaruh Lingkungan, 39
} 
Orang tua yang suka memuji dan member dorongan yang positif bagai anaknya adalah orang tua yang bijaksana dalam mempersiapkan anak untuk dapat berkompetisi di masa yang akan datang. Jika orang tua terbiasa menggunakan afirmasi yang negative maka, anak akan memetik hasil yang negative pula.

Afirmasi yang diberikan kepada seorang anak rermaja, haruslah betul-betul dapat mendorong dan memacu si remaja untuk bisa mandiri, percaya diri, dan berkreasi sebagaimana mestinya. Anak yang rendah diri biasanya tidak memiliki percaya diri, mudah menyerah, dan mempunyai kecenderungan sulit untuk menyesuaikan diri dengan lingkungan. Selanjutnya dikatakan pada mereka yang memiliki konsep diri yang rendah, rentan terhadap frustrasi, dan akan melampias-kannya baik pada diri sendiri maupun orang lain. Anak yang memiliki rasa percaya diri yang kurang, memerlukan pemahaman orang tua. Orang yang paling dekat dalam pembentukan kepribadian anak adalah orang tua. Orang tua harus mengenali kemampuan dan menghargainya sebagai pribadi dan bukan sebagai objek yang harus memenuhi tuntutan semata.

Anak juga di dorong untuk memiliki sikap kemandirian dan juga ketrampilan tertentu yang menjadi bagian penting untuk memaksimalkan rasa percaya diri. Rasa mampu pada anak akan menjadi indikasi positif bagi anak untuk mengembangkan diri, selanjutnya anak akan lebih mudah untuk menghargai diri sendiri. $^{31}$

Hal yang terpenting yang harus dirmiliki oleh orang tua adalah dengan menunjukkan sikap peduli. Sebelum anak mampu menerima diri sendiri apa adanya, orang tua harus lebih dahulu menerima anak apa adanya.

Remaja membutuhkan penghargaan secara intelektual untuk belajar berpikir secara baik, untuk bisa berpikir secara positif kreatif, orang menjadi respek terhadap dirinya bukan hanya secara emosional dan fisik saja, tetapi juga intelektual. Jika orang tua ingin melihat remajanya merasa bahwa ia dikasihi berikanlah mereka dorongan atau penghargaan secara intelektual melalui mendengarkan, dan perkataan terhadap apa yang mereka pikirkan dan sampaikan. Agar anak tumbuh percaya diri memang tidak terjadi secara instan, tetapi memerlukan suatu proses, keterlibatan keluarga sebagai orang terdekat dari anak sangat membantu mereka untuk memiliki penilaian positif pada dirinya.

Penghargaan secara spiritual atau rohani dapat dilakukan orang tua dengan cara: parents much teach teir teenager spiritual concerns. Parents much share their own experiences. Parents should be examples of forgiveness. ${ }^{32}$

\footnotetext{
${ }^{31}$ Elia Daryati, R. "Kemandirian Anak”, Harian Pikirang Rakyat, 5 Agustus 2007, 15

${ }^{32}$ Campbell, How to Really, 107.
} 


\section{Faktor Lingkungan}

Manusia mempunyai naluri untuk hidup berkumpul dengan orang lain, karena memang manusia itu tidak diperlengkapi dengan alat-alat yang cukup untuk dapat hidup sendiri di dunia. Oleh karena itu tidaklah mengherankan jika si remajapun senang hidup berkumpul dengan kawan-kawannya, walaupun hal itu tidak selalu membawa pengaruhpengaruh yang baik.

Remaja sangat mudah terpengaruh oleh lingkungan luar dan dalam. Lingkungan luar dan pengaruhnya kadang-kadang peril di hambat dan di cegah supaya tidak terlalu besar perangsangnya terutama bila itu bersifat negatif. ${ }^{33}$

Masa remaja adalah masa dimana seorang anak dalam proses pencarian identitas diri, masa dimana remaja sedang mencoba untuk keluar dari suatu lingkungan yang selama ini telah menjadi tempat dia belajar dan mendapatkan disiplin serta tempat ia bisa melihat teladan.

Namun begitu seorang anak memasuki masa remanja, ia mulai berusaha untuk meninggalkan keluarganya, dan mencari teman ataupun orang-orang yang dalam pandangannya bisa dijadikan teman bahkan idola. Di sinilah lingkungan tempat yang paling tepat bagi dia, baik itu lingkungan sekolah, rumah, atau lingkungan tempat si anak beraktivitas seperti tempat kursus, olah raga, pramuka dan lain-lain.

Seringkali pengalaman dan tekanan lingkungan membuat para remaja dihinggapi rasa rendah diri. Orang tua perlu menyadarkan remaja bahwa keinginan tanpa usaha yang tekun adalah sia-sia. Remaja harus didorong untuk menonjolkan kelebihan yang ada padanya agar bisa melupakan kelemahannya dan bertumpu pada kelebihannya. ${ }^{34}$

Seorang remaja cenderung untuk menilai dirinya berdasarkan apa yang dikatakn orang, kelompok atau lingkungannya. Harga diri seorang anak usia sekolah amat dipengaruhi oleh cara kelompoknya memandang serta menghargai dia. ${ }^{35}$

Pengaruh kawan-kawan memang sangat besar terhadap seorang anak remaja. Pada usia ini ada rasa kebanggan tersendiri bahwa remaja mempunyai banyak kawan, oleh karena merasa dirinya popular. Ketika mereka merasa dirinya sangat popular pada saat itulah ia merasa percaya diri. Skala nilai dan norma yang baru biasanya diperoleh melalui proses identifikasi dengan orang yang dikagumi. Orang tua biasanya berperan dalam pembentukan ini, terutama dengan uraian dan keterangan mengenai keyakinan dalam agama yang dianutnya.

Hal yang terkait erat dengan identitas diri dan harga diri, kelompk adalah etnosentrisme (etnhnocentrisme), yakni kecenderungan untuk lebih menyukai

\footnotetext{
${ }^{33}$ Singgih Gunarsah dan Yulia Singgih D. Gunarsah, Psikologi Perkembangan Anak dan Remaja,(Jakarta: BPK Gunung Mulia, 1983), 212.

${ }^{34}$ Dominggus E. Naat, "Remaja dan Persoalannya," Buletin Gema Anugerah, 23

${ }^{35}$ Wanda Humble, Dikata Kuliah Psikologi Perkembanagn Anak, Sem I (STTII, 1997), 6
} 
kelompoknya sendiri melebihi kelompok-kelompok lain. ${ }^{36}$ Masa remaja adalah masa fase yang paling penting dalam pembentukan nilai. Pembentukan nilai merupakan suatu proses emosional dan intelektual yang sangat dipengaruhi oleh interaksi sosial

\section{Faktor Harga Diri dan Konsep Diri menurut Pandangan Alkitab}

Dalam pembentukan kepercayaan diri bagi orang Kristen perlu dilihat dari sisi pengenalan mereka kepada Allah, pengenalan terhadap diri sendiri yang kesemuanya harus di mulai dri pemahamannya terhadap Firman Allah, terutama dari riwayat penciptaan yang tertulis dalam Kitab Kejadian, serta pemeliharaan Allah terhadap hasil ciptaaanNya.

Manusia adalah Sebagai Ciptaan yang Paling Mulia

(Kejadian 1:27-31; Mazmur 8)

Dari permulaan Alkitab, manusia memiliki tempat yang khusus di hati Allah, lebih dari segala ciptaan-Nya dan yang terutama dari segala makhluk hidup. Manusia dihembusi nafas Allah sendiri, dan dengan demikian dianugerahi suatu kesamaan dengan Penciptannya, yang memungkinkan manusia dapat berkomunikasi dan memiliki pengetahuan yang pasti dan setelah penciptaaan manusia Allah berkata "sungguh amat baik", Kejadian 1:31, berbeda dengan penciptaan yang lain pada ayat-ayat sebelumnya, ketika Allah melihat hasil ciptaanNya yaitu tumbuh-tumbuhan, binatang-binatang dan lain sebagainya, Allah hanya berkata: "semuanya itu baik".

Dalam penciptaan yang mula-mula itu manusia mempunyai arti yang sangat penting sekali. Kepada manusia diberikan kuasa untuk memerintah segala ciptaan lainnya.

Berfirmanlah Allah, "Baiklah Kita menjadikan manusia menurut gambar dan rupa Kita, supaya mereka berkuasa atas ikan-ikan di laut dan burung-burung di udara dan atas ternak dan atas seluruh bumi. Maka Allah menciptakan manusia itu menurut gambar-Nya, menurut gambar Allah ciptkan-Nya dia.” (Kejadian 1:26-27)

Manusia adalah "Imago Dei" (Kejadian 1:26-27)

Dalam Kejadian 1:26 "Baiklah Kita menjadikan manusia menurut gambar dan rupa Kita..." Kata ganti orang pertama jamak (kita) di sini bisa menunjuk kepada Allah. Kata Ibrani untuk 'manusia' di sini adalah Adam. Dalam bahasa Ibrani Adam berasal dari kata yang sama untuk 'tanah' (adama). Ini juga nama manusia pertama yang diciptakan oleh Allah (Kej 3:20). Manusia diciptkan "menurut gambar dan rupa" Allah, yang berarti memiliki hubungan istimewa dengan Allah dan mewakili Allah di bumi dengan berkuasa atas makhluk-makhluk lain. ${ }^{37}$

\footnotetext{
${ }^{36}$ Jhonn W. Santrock, "Life-Span Development”, 359

${ }^{37}$ Alkitab Edisi Studi: Lembaga Alkitab Indonesia,. Cetakan 2013, 36.
} 
Allah menciptakan manusia Adam dan member dia tujuan yang berarti, yang ilahi dari keberadaannya: untuk memerintah atas segala makhluk lain ciptaan Allah. Pada waktu diciptakan Adam tidak saja diberikan peranan yang berarti dan penuh kuasa, tetapi juga menikmati perasaan aman dan terjamin. ${ }^{38}$

Dua pasal pertama dalam Kejadian sangat bermakna bagi psikolog.Di samping segala keuntungan yang lain,kedudukn sebagai umat yang diciptakan langsung oleh Allah,serta memiliki kewenangan atau kuasa atas segala ciptaan Allah yang lain,seperti tumbuhan dan hewan,dan sifat istimewa yaitu memiliki gambar dan rupa Allah itu merupakan dasar harga diri yang tinggi.

Dari berbagai arti yang banyak di tawarkan oleh para ahli,yang paling mendasar yakni:potensi/kemampuan manusia untuk berhubungan atau merespon Allah.Dan dalam arti ini manusia adalah makhluk religius.Manusia diciptakan sedemikian rupa untuk menjadi pihak lain dengan siapa Allah berkomunikasi(menyatakan diri dan kehendakNya serta menuntut responnya). Kenyataan bahwa Allah berfirman atau member perintah kepada manusia adalah bukti bahwa manusia dengan satu dan lain cara dapat menyatakan hubungannya dengan Allah. Penciptaan manusia sebagai gambar Allah memungkinkan terjadinya sesuatu antara Allah dan manusia,yaitu makhluk dengan siapa Allah berhubungan dan kepada siapa Ia berfirman (band.Kej.1:27). ${ }^{39}$

Alkitab menggambarkan hubungan manusia dengan Allah penciptanya,sebagai tanah liat di tangan penjunan.Allah berhak dan berdaulat untuk tujuan apa benda-benda atau peralatan tanah liat dibuat-Nya.Demikianlah manusia di tangan Allah pencipta,tujuan hidupnya ditentukan oleh khaliknya.

Harga diri adalah kebutuhan psikologis manusia yang paling menonjol pada masa kini. Masalah nilai diri adalah masalah identitas. Nilai diri seseorang akan muncul bila ia mengetahui siapa dia sesungguhnya, yaitu bahwa ia adalah anak Allah. Pengetahuan dan pengenalan diri berdasarkan Firman Allah memperkokoh ketahanan manusia terhadap setiap kepahitan hidup, karena sadar sebagai makhluk yang dikasihi dan khususkan oleh Allah yang tidak tergantung kepada situasi dan kondisi lingkungan.

Lebih jelas pemazmur dalam Mazmur 8:6-7 mengatakan bahwa manusia yang hina dijadikan Allah sebegitu rupa sehingga menjadi berharga:"Namun Engkau telah membuatnya hamper sama seperti Allah, dan telah memahkotainya dengan kemuliaan dan horma. Engkau membuat dia berkuasa atas buatan tangan-Mu; segala-galanya telah Kau letakkan di bawah kakinya. ${ }^{40}$

Tuhan memberi manusia "kemuliaan dan hormat: seseorang raja dan kuasa untuk memerintah. Ayat-ayat ini mengingatkan pada Kejadian 1:26-28, yang mengakatan bahwa

\footnotetext{
${ }^{38}$ Neil T. Andersen: "Siapa Anda Sesungguhnya., Menyadari Kuasa Identitas Anda di dalam Kristus, (Bandung: Lembaga Literatur Baptis), 31

${ }^{39}$ Pendidikan Agama Kristen: Matakuliah Pengembangan Kepribadian (Jakarta: Depag Bimas Kristen Protestan, 2006), 69

${ }^{40}$ Lembaga Alkitab Indonesia "Alkitab Edisi Studi” 2013, 875
} 
manusia akan memerintah atas semua ciptaan karena Allah menciptakan manusia menurut gambar-Nya".

Dengan mengacu pada karya Allah bagi manusia itulah sebenarnya yang menjadi dasar bagi setiap orang untuk menjadi percaya diri. Stanly Heath berkata: "melihat kebutuhan manusia untuk harga diri yang sangat dirasakan semua orang, maka orang Kristen harus sangat berterima kasih bahwa dasar harga dirinya tidak dapat hilang. Dasarnya adalah Allah sendiri yang mempunyai rencana bagi kita masing-masing. ${ }^{41}$

Manusia adalah ciptaan Allah yang paling mulia dan berharga karena manusia adalah merupakan "gambar dan rupa Allah" sendiri. Tetapi gambar Allah itu sudah menjadi rusak ketika manusia pertama jatuh dalam dosa, sehingga gambar Allah yang begitu indah dan luar biasa itu menjadi pudar.

Itulah sebabnya untuk mendapatkan kembali gambar diri manusia yang telah rusak itu, maka Allah sendiri datang ke dalam dunia untuk memperbaikinya dengan jalan mengutus Anak-Nya Yesus mati di atas kayu salib sehingga manusia yang sudah rusak dan berdosa itu dapat diselamatkan dan memiliki gambar diri yang jelas di dalam Tuhan. Menjadi seorang Kristen bukan hanya soal mendapatkan sesuatu, melainkan soal menjadi orang yang mempunyai identitas diri yang baru. Seorang Kristen, menurut identitasnya yang paling mendalam dan mendasar adalah seorang kudus, seorang anak Allah, seorang yang sudah dilahirkan kembali secara rohani, suatu karya agung, anak terang, warga kerajaan surga. ${ }^{42}$

Setiap orang Kristen di dalam Tuhan sudah jelas, karena itu apa yang harus dilakukan oleh orang Kristen itu juga jelas seperti yang ada dalam firman Tuhan: 2 Korintus 5:17 “...ciptaan baru...”, Efesus 2:10 “...diciptakan dalam Kristus untuk melakukan pekerjaan baik...” 1 Petrus 2:9 “... memberitakan perbuatan-perbuatan yang besar ...,43

Penting sekali bagi seorang anak remaja untuk mengerti identitasnya di dalam Yesus Kristus kalau orang tua ingin anak remajanya berhasil dalam menjalani kehidupannya sebagai orang remaja dan juga sebagai seorang remaja Kristen.

Salah satu tugas orang tua yang terpenting adalah untuk mengembangkan konsep pribadi yang sehat secara emosional dan tepat menurut Alkitap dalam diri anak.Tanpa harga diri,anak tidak akan mampu mencapai kemampuan yang telah diberikan Allah kepada mereka dan yang harus mereka kembangkan. Rasa sakit secara emosional pada umumnya akibat tiga (3) hal yaitu:pertama, kurang harga diri. Kedua, kurang akrab dengan orang lain. Ketiga, kurang akrab dengan Allah. ${ }^{44}$

Usia remaja adalah usia dimana si anak sedang dalam proses menemukan jati diri yang sesungguhnya. Jika dalam usia ini mereka tidak bisa menemukan jati diri mereka yang sebenarnya maka, itu akan mempengaruhi mereka pada waktu mereka dewasa nanti.

\footnotetext{
${ }^{41}$ Stanly Heath; "Kumpulan Makalah Lepas" (Bandung: IAT), 87. 1990), 58

42 Josh McDowell \& Bill Jones: "Tanya - Jawab Kawula Muda", (Yogyakarta: Yayasan ANDI,

${ }^{43}$ Lembaga Alkitab Indonesia

${ }^{44}$ Dr. James C. Dobson: "Menjadi Orang Tua Bukan untuk Orang-orang Pengecut." (Harvest Publication House: 1996), 55
} 
Perasaan rendah diri yang mungkin sudah terbawa dari kecil akan mempengaruhinya. Salah satu contoh yaitu si anak remaja itu akan merasa bahwa ia tidak mampu untuk melakukan apapun. Oleh karenanya harus ada usaha -usaha yang dilakukan untuk mengatasi rasa rendah diri tersebut.

Usaha-usaha awal yang sebaiknya dilakukan untuk mengatasi rasa rendah diri tersebut adalah suatu kesadaran bahwa keinginan-keinginan saja (tanpa usaha yang penuh ketekunan) adalah sia-sia belaka. Yang diperlukan adalah kesanggupan untuk mengambil keputusan-keputusan yang tepat dan membentuk kepribadian yang kuat. $^{45}$

Pengaruh penting lainnya yang ikut mempengaruhi perkembangan harga diri anak adalah pengaruh sistem nilai yang dianut oleh orang tua. Pada hakekatnya ada tiga unsur yang mempunyai pengaruh terhadap pembentukan identitas diri manusia. Unsure yang pertama yaitu: sifat -sifat atau karakternya yang telah berkembang sejak masa kanakkanak. (Orang tualah yang menjadi panutan, yang menjadi cermin bagi si anak adalah karakter dan sifat orang tua). Unsur yang kedua adalah: keadaan dan cara bagaimana perasaan "memberontak" tersebut terwujud dalam arti yang positif. Arti yang positif inilah yang kelak akan mempunyai pengaruh yang menentukan bagi pembentukan identitasnya. Unsur yang ketiga yaitu: sifat serta kebutuhan-kebutuhan dari zaman yang sedang dialami ini, atau yang sering dikenal dengan cara teknologi dan lain sebagainya. ${ }^{46}$

Dengan melihat pada ketiga unsur yang mempengaruhi terhadapa pembentukan identitas anak tersebut, maka disinilah letak tanggung jawab orang tua untuk dapat meletakkan dasar yang baik kepada anak-anaknya.

Anak-anak seperti spons. Mereka menyerap nilai-nilai dari suatu tempat. Jadi meskipun anda (orang tua) tidak memengaruhi mereka, orang lain akan melakukannya. Nyatanya, jika anda tidak memengaruhi anak anda, andalah satusatunya orang dalam hidup mereka yang tidak melakukan hal itu. Orang lain akan melakukannya untuk anda, tetapi dengan nilai-nilai dan standar meraka, bukanlah nilai-nilai dan standar anda. ${ }^{47}$

Orang tua yang harusnya menurunkan nilai-nilai kebenaran kepada anak-anak mereka, membantu mengembangkan semacam "kronometer moral". Ke mana pun mereka pergi nantinya, dan apa pun yang mereka lakukan dalam hidup ini, mereka akan bisa memercayai penilaian mereka sendiri dan mengambil keputusan moral yang baik menggunakan nilai-nilai kebenaran yang mereka pelajari dari orang tua sebagai titik acuan

${ }^{45}$ Soerjono Soekamto: "Remaja dan Masalah-masalahnya: Sebab-musabab dan Pemecahannya. (Jakarta: BPK Gunung Mulia, 1989), 61

${ }^{46}$ Ibid, Soerjono Soekamto, 85

${ }^{47}$ Steve Chalke; "Kiat menjadikan Anak Anda Sukses \& Bahagia” (Yogyakarta: ANDI,2009), 154 
yang dapat dipercaya. Tanpa nilai-nilai moral dari orangtua, anak-anak akan seperti berada di tengah lautan.

Oleh karenanya penulis Amsal dalam Amsal 22:6 berkata "Didiklah orang muda menurut jalan yang patut baginya, maka pada masa tunya pun ia tidak akan menyimpang dari pada jalan itu." 48

Manusia Berharga di Mata Allah (Yesaya 43:3-5)

Remaja pada masa ini sedang merenggang diri dari ikatan emosional orang tuanya. Mereka sedang membongkar landasan hidup yang sudah diletakkan orangtuanya. Pada masa ini remaja harus menemukan identitas dirinya. Ikatan pribadi pada masa ini sangat penting untuk pembentukan identitas diri. Pada masa ini juga remaja sedang mencari tokoh idola yang dapat dijadikan contoh atau model. Jika banyak tokoh yang berhasil, yang dilihat atau diidolakan menolong remaja untuk dapat mengidentifikasikan diri dengan tokoh-tokoh tersebut.

Ketika seorang remaja mencoba untuk mengidentifikasikan dirinya dengan idolanya, sebenarnya ia sementara mencari jati dirinya dan kepribadiannya. Sebagai orang lain, anak remaja Kristen perlu ditolong untuk mengetahaui bahwa mereka berharga di mata Allah tanpa harus menjadi seperti orang lain. Pemahaman ini dilandasi dengan kebenaran-kebenaran firman Tuhan.

Dalam Yesaya 43:4; dengan jelas dikatakan bahwa: "Oleh karena engkau berharga di mata-Ku dan mulia, dan Aku ini mengasihi engkau..." Allah mengasihi manusia ciptaan-Nya yang serupa dan segambar dengan Dia. Manusia berharga, karena manusia adalah ciptaaan Allah yang sempurna, bahkan ketika manusia jatuh dalam dosa, dikatakan bahwa Allah menebusnya. Lebih lanjut dikatakan dalam Mazmur 8:4-6 bahwa: “ ... namun Engkau telah membuatnya hamper sama seperti Allah..."

Dengan melihat pernyatan-pernyataan firman Allah, jelas manusia berharga di mata-Nya, Allah memandang manusia begitu luar biasa dibandingkan dengan ciptaan-nya yang lain. Bukan itu saja (berharga) tapi juga Allah mengasihi manusia, itulah sebabnya untuk membangun atau membentuk rasa percaya diri seorang remaja, sebagai orang Kristen mulai dengan melihat siapa dia sebenarnya di dalam Kristus dan juga melihat bagaimana Allah memandangnya sebagai seorang pribadi yang sangat berharga. ${ }^{49}$

Karena manusia itu sangat berharga di mata Allah, maka ketika manusia itu jatuh dalam dosa Allah sendiri mengambil inisiatif untuk menyelamatkannya, karena Allah mengerti dan tahu pasti bahwa manusia tidak akan sanggup untuk dapat membangun kembali hubungan yang sudah rusak antara manusia dengan diri-Nya. Ia mengutus AnakNya yaitu Yesus Kristus, dan dikatakan dalam Yohanes 3:16 bahwa “...barangsiapa yang percaya kepada-Nya tidak binasa, melainkan beroleh hidup yang kekal." Jika seorang di

\footnotetext{
${ }^{48}$ Akitab, Jakarta: LAI, 2009.

${ }^{49}$ Neil T. Anderson. "Siapa Anda Sesungguhnya”, Lembaga Literatur Baptis (Bandung: 1997), 72
} 
bawa untuk mengenal Kristus secara pribadi maka, masalah kurang percaya diri ini akan terselesaikan, oleh karena ia mengerti dengan jelas identitas dirinya di dalam Yesus.

Oleh karena keselamatan anak-anak itu sangat penting, maka ajarkanlah anak untuk bertumbuh dalam iman dengan cara orang tua sendiri haruslah menjadi teladan, serta pengajaran yang terus menerus seperti yang dimaksud dalam Ulangan 6:6-9.Firman Tuhan dengan jelas memberikan perintah kepada orangtua untuk dapat mendidik anak-anak mereka sesuai dengan kebenaran yang ada. Orang tua adalah teladan hidup anak.

Kebanyakan nilai-nilai anda (orangtua ditangkap tanpa sengaja. Sebelum mereka (anak) bisa membuat "penilaian", anak akan meniru perkataan dan perbuatan anda, baik secara sadar maupun tidak. Mereka akan mengikuti gerak tubuh dan lagak anda tanpa disadari. Namun, mereka juga akan menerima sebagian nilai-nilai anda. ${ }^{50}$

Jadi jika orang tua tidak mau anaknya mempelajari sesuatu yang tidak baik sebagai orangtua jangan lakukan. Apapun yang orangtua katakana kepada anak tentang nilai-nilai akan mereka lihat apakah semua itu benar-benar dipraktekkan dalam kehidupan orangtua. Semua orangtua adalah teladan. Cara orangtua mengasuh anak adalah salah satu faktor paling penting dalam menentukan akan mejadi apa mereka kelak.

\section{Wujud Nyata dari Kepercayaan Diri Remaja}

Pendidikan akademis dan pendidikan karakter adalah dua hal yang tidak bisa dipisahkan sehingga karakter atau nilai yang di tanamkan terintegrasi dalam setiap pembelajaran yang bersifat akademis. Pendidikan karakter atau nilai tidak pernah diajarkan melalui hafalan ataupun ujian tertulis, tetapi selalu terintegrasi dalam setiap pembelajaran akademis anak. Oleh karena adanya keterkaitan antara pendidikan akademis dan karakter atau nilai, maka dapatlah dilihat bahwa seorang anak yang memiliki kepercayaan diri yang baik akan memiliki atau menunjukkan:

\section{Percaya akan Kompetensi Diri Sendiri}

Anggapan umum bahwa orang tua tidak bisa memenuhi minat dan kemampuan dalam mendidik anak-anak mereka, begitu anak-anak mencapai usia 6-7 tahun, mungkin merupakan pandangan peninggalan masa lalu. Masa lalu yaitu masa dimana tidak banyak orang tua yang mempunyai ketrampilan baca tulis atau merupakan imingran yang tidak memiliki ketrampilan yang dibutuhkan anak-anak mereka untuk bisa berfungsi dalam masyarakat industri modern. ${ }^{51}$ Tetapi sekarang kebanyakan orangtua memiliki kemampuan

\footnotetext{
${ }^{50}$ Steve Chalke; "Kiat menjadikan Anak sukes \& bahagia", 163

${ }^{51}$ Dr. Singgih Gunarsa, "Psikologi Perkembangan Anak dan Remaja", 132.
} 
untuk mengajarkan anak-anak mereka sendiri, dan mampu mengajar anak mereka dengan lebih baik daripada seorang guru di sekolah formal. Keberhasilan orang tua mengajar atau mendidik anak mereka sendiri ini didasarkan pada pengamatan mereka terhadap kemampuan dan kreatifitas anak, yang mungkin tidak didapatkan di sekolah formal.

Ketika seorang anak remaja mendapatkan pendidikan yang sesuai dengan minat dan kemampuannya, maka anak tersebut akan bertumbuh menjadi anak yang dapat mengerti akan kualitas dan kompetensi dirinya sendiri.

Seorang remaja yang percaya akan kompetensi atau kemampuan dirinya tidak membutuhkan pujian, pengakuan, penerimaan, ataupun rasa hormat dari orang lain. Hal ini dapat dilihat melalui bagaimana seorang anak itu dapat mengemukakan pendapatnya ketika ia berada di suatu lingkungan atau komunitas. ${ }^{52}$

\section{Dapat Menjadi Diri Sendiri}

Seorang anak remaja memiliki rasa percaya diri yang baik ialah seorang remaja yang tidak terdorong untuk menunjukkan sikap konformis demi diterima orang lain atau kelompok. Seorang remaja yang percaya diri berani menerima dan mengahadapi penolakan orang lain atau lebih tepat ia berani menjadi diri sendiri. Dalam hal ini ia sanggup untuk menerima resiko apapun dari setiap keputusan yang diambil atau yang dihadapi. $^{53}$

Dengan kata lain remaja ini adalah remaja yang mengerti siapa dirinya yang sesungguhnya karena ia memiliki identitas yang jelas, sehingga diperhatikan ataupun tidak diperhatikan orang lain, ia mampu mengaktulisasikan dirinya tanpa harus melihat dan mendengar apa pendapat orang mengenai dirinya. Seseorang yang memiliki motivasi untuk berprestasi tidak begitu mementingkan penghargaan. Penghargaan baginya bukanlah penting, tetapi penghargaan lebih sering merupakan hal yang sekunder setelah kepuasan internal tercapai.

Aktualisasi diri melebihi pemikiran rasional yang sering menganggap rendah dan membatasi diri sendiri. Banyak orang berbakat dan pandai yang gagal menemukan tujuan hidupnya, sampai segala sesuatu terlambat. Aktualisasi diri lebih dekat pada intelegensi murni daripada kepandaian saja. Orang yang cerdas cenderung mengetahui apa yang mereka inginkan dan ke mana tujuan hidupnya.

\section{Memiliki Self Control yang Baik}

Seseorang yang memiliki rasa percaya diri biasanya mempunyai pengendalian diri yang baik (tidak moody dan emosinya stabil, ia memiliki internal locus of control (memandang keberhasilan atau kegagalan, tergantung dari usaha sendiri dan tidak mudah

\footnotetext{
52 Jacinta F. Rini, "Percaya Diri”, Tien Cyber Indonesiablog, Agustus 2006

${ }^{53}$ Wanda Humble, "Diktat Kuliah ; Psikologi Perkembangan (Yogyakarta: STTII)
} 
menyerah pada nasib atau keadaan serta tidak tergantung atau mengharapkan bantuan orang lain). ${ }^{54}$

Orang-orang yang memiliki keyakinan besar terhadap perasaan-perasaan mereka adalah juru mudi yang lebih baik bagi hidup mereka. Mereka tampak lebih pasti dengan keputusan-keputusan pribadi mereka, mulai dari siapa yang akan mereka nikahi sampai pekerjaan apa yang akan mereka lakukan. Kesadaran diri emosionil adalah bagian dari 'bebas buta emosi' dan sebuah tanda keseimbangan dan kedewasaan. $^{55}$

Pentingnya emosi karena tubuh manusia berkomunikasi dengan dirinya sendiri dan dengan orang lain untuk mengatakan apa yang dibutuhkannya. Makin baik komunikasi, makin baik pula perasaan seseorang. Emosi juga memiliki potensia untuk mempersatukan dan menghubungkan manusia. Jadi kesadaran seseorang terhadap emosinya dan pengelolaan terhadap emosi tersebut secara berhasil mengkombinasikan tiga komponen emosi yaitu kognitif, fisik dan perilaku disebut kecerdasan emosi. ${ }^{56}$

Kecakapan pribadi ini akan memberi kebebasan kepada anak didik untuk dapat mengenali dirinya sendiri. Ini berarti dapat bersikap jujur terhadap diri sendiri dan juga terhadap orang lain. Kemampuan untuk memantau perasaan dari waktu ke waktu adalah hal yang penting bagi pemahaman jiwa secara mendalam dan pemahaman diri. Orang yang tidak memiliki kesadaran diri seperti ini sering 'meledak' secara emosional jika di bawah tekanan.

Karakteristik pribadi seperti ini tidak membutuhkan bakat khusus yang diturunkan (genetic). Juga tidak membutuhkan ketrampilan-ketrampilan pengetahuan diri, seperti meditasi, yang diperoleh selama bertahun-tahun. Hal ini berkaitan dengan masalah berpikir dan menjadi dari pada melakukan. ${ }^{57}$

Seorang anak yang bertumbuh mampu menangani berbagai emosi yang dialaminya. Semakin ia dewasa, emosi anakpun semakin kompleks. Seorang anak perlu belajar menamai emosi yang ia alami, menemukan penyebabnya, maknaya, penggunaannya yang destruktif dan konstruktif, serta bagaimana mengekspresikannya dengan tepat.

Seorang anak yang bertumbuh mampu menangani stress, bahkan serangan bertubitubi dari berbagai peristiwa buruk yang menimbulkan stress. Dengan 'kemampuankemampuan emosional' seperti itu, biasanya anak didik akan mendapatkan apa yang ia inginkan dengan hasil yang lebih efektif.

\footnotetext{
${ }^{54}$ Buletin “Achieving True Success: How to Build Character as a Family” (International Association of Character Cities, IACC)

${ }_{55}^{5}$ Harry Alder, "Boost Your Intellegence” (Jakarta: Penerbit Erlangga, 2001), 80

${ }^{56}$ Thomas Armstrong, Ph.D; "7 Kinds of Smart", Menemukan dan Meningkatkan Kecerdasan Anda berdasarkan Teori Multiple Intellingence”, (Jakarta: Gramedia Pustaka Utama, 2002), 34.

${ }^{57}$ Alder: Pacu EQ dan IQ anda (Jakarta: Penerbit Erlangga, 2001), 82
} 


\section{Memiliki Pandangan yang Benar terhadap Diri Sendiri dan Orang Lain}

Seorang mulai mengenal siapa dirinya dan akan menjadi dirinya, itu bermula dari adanya identitas yang jelas mengenai dirinya sendiri. Di dalam setiap tahapan dalam hidupnya, self esteem selalu akan berubah dan berkembang. Seseorang akan menjadi lebih teguh ketika identitasnya bertumbuh.

Ketika seorang anak remaja mengenal dan mengerti dengan jelas siapa dirinya, maka itu akan mempengaruhi cara pandangnya terhadap diri sendiri dan terhadap orang lain yang ada di luar dirinya. Memberikan penilaian bagi diri untuk segala sesuatu yang diupayakan, melalui pemusatan perhatian kepada apa yang dilakukan, dengan seseorang menghargai dirinya atas upaya-upaya yang dilakukan dari pada menekankan akhir hasil kerja. ${ }^{58}$

Seorang anak yang bertumbuh pasti memiliki cara pandang yang benar terhadap diri sendiri dan juga orang lain, memiliki rasa peduli terhadap keluarga, teman-temannya dan bukan hanya pada kebutuhannya sendiri. Seorang anak remaja akan mulai menanamkan nilai-nilai bagi dirinya sendiri. Jika ia mempunyai nilai' kejujuran' itu berarti bahwa ia menganggap penting untuk bersikap jujur, dan biasanya semua tujuan atau maksud utama itu harus cocok dengan nilai-nilai kejujuran tersebut.

\section{Memiliki Harapan yang Realistik terhadap Diri Sendiri}

Anak-anak yang memiliki rada percaya diri yang baik mempunyai tujuan-tujuan yang realistis. Mereka mampu memandang masa depan mereka dan bergerak meraih suatu tujuan. Mereka mungkin mengalami kemunduran, tetapi mereka akan terus menemukan cara-cara lain untuk mencapai apa yang ingin mereka raih, sehingga ketika harapan itu tidak terwujud, ia tetap mampu melihat sisi positif dirinya dan situasi yang terjadi dan mereka ingin terus maju. ${ }^{59}$

Ambisi anak remaja dapat dipengaruhi oleh ambisi orangtua. Dimana ambisiambisi orang tua terhadap anak-anak berasal dari kegagalan masa lalu yang dialami orang tua dan menginginkan anak dapat mencapainya. Namun bagi seorang anak remaja yang memiliki rasa percaya diri yang baik, akan mempergunakan semua ambisi itu baik dari orang tua maupun dari luar untuk mencapai harapan atau cita-citanya. Tentunya dengan tidak melepaskan diri dari realitas kehidupannya.

Ada beberapa sifat lain dari kepribadian-kepribadian yang sehat (memiliki rasa percaya diri yang sehat). Mereka berorientasi kepada masa depan, diarahkan

\footnotetext{
${ }^{58}$ Jason Lase, "Motivasi Berprestasi”, 107.

${ }^{59}$ Steve Chalke: "Kiat menjadikan Anak Anda Sukses \& Bahagia”, 85
} 
kepada tujuan-tujuan dan tugas-tugas yang akan datang. Mereka harus memiliki alasan untuk meneruskan kehidupan, untuk menyelesaikan tujuan yang akan datang kalau tidak kehidupan itu akan kehilangan arti. ${ }^{60}$

Orang-orang yang sehat secara psikologis mengetahui diri mereka, siapa dan apa mereka. Orang-orang serupa itu menyadari kekuatan-kekuatan dan kelemahan-kelemahan, kebaikan-kebaikan dan keburukan-keburukan mereka, dan umumnya mereka sabar dan menerima terhadap hal-hal tersebut secara realistis. Mereka tidak berkeinginan untuk menjadi sesuatu yang bukan diri mereka. Meskipun mereka dapat memainkan perananpernanan sosial untuk memenuhi tuntutan dari orang lain atau situasi-situasi.

Orang-orang yang sehat secara psikologis tidak hidup dalam masa lampau. Pandangan terhadap masa depan sebagai sesuatu yang sangat penting bagi kepribadian yang sehat. Orientasi mereka harus ke tujuan-tujuan dan tugas-tugas yang akan datang, tetapi mereka juga menyadari dan menaruh perhatian pada kehidupan sekarang yang terus menerus berlangsung. ${ }^{61}$

Ada juga yang melihat bahwa salah satu wujud nyata dari seorang remaja yang memiliki rasa percaya diri yaitu, dengan kemampuannya untuk dapat berkomunikasi dengan orang lain atau yang sering disebut dengan kemampuan interpersonal yang juga merupakan salah satu bagian dari kecerdasan ganda. Ini adalah kemampuan untuk memahami dan bekerjasama dengan orang lain. Kecerdasan ini terutama menuntut kemampuan untuk menyerap dan tanggap terhadap suasana hati, perangai, niat, dan hastrat orang lain. Orang lain yang memiliki kemampuan interpersonal bisa mempunyai rasa belas kasihan dan tanggung jawab sosial.

\section{Kesimpulan}

Kepercayaan diri seorang remaja dapat terbangun secara sehat dan kuat dipengaruhi oleh berbagai factor, diantaranya adalah lingkungan dimana anak itu bertumbuh. Keluarga menjadi tempat pertama dalam pembentukan karakter dan juga harga diri atau nilai diri anak.

Selain factor keluarga, ada juga factor yang paling hakiki atau mendasar yaitu factor harga diri atau menilai diri sesuai dengan pandangan Alkitab atau sesuai dengan cara Allah memandang ciptaanNya yaitu bahwa manusia itu berharga di mataNya: "Sebab Akulah Tuhan, Allahmu, Yang Mahakudus, Allah Israel, Juruselamatmu. Aku menebus engaku dengan ... Oleh karena engkkau berharga di mata-Ku dan mulia, dan Aku ini mengasihimu, maka Aku memberikan manusia sebagai gantimu..." (Yes. 43:3-4)

\footnotetext{
${ }^{60}$ Schultz, Psikologi Pertumbuhan, 160.

${ }^{61}$ Chalke, Kiat menjadikan Anak Anda Sukses \& Bahagia, 92
} 
Ketika seorang anak remaja dapat menilai dirinya sesuai dengan cara Allah memandangnya dan mengerti serta menghargai pengorbanan Allah baginya melalui Yesus Kristus, maka itu dapat menolong nya lebih percaya diri, karena ia memiliki indentitas yang jelas di dalam Tuhan. 


\section{DAFTAR PUSTAKA}

Akitab, Jakarta: LAI, 2009

Alder, Harry.Boost Your Intellegence. Jakarta: Penerbit Erlangga, 2001

Alkitab Edisi Studi: Lembaga Alkitab Indonesia,. Cetakan 2013

Allport, G. Becoming: Basic Consideration for a Psychology of Personality. New Heaven: Yale University Press, 1995

Andersen, Neil T. Siapa Anda Sesungguhnya: Menyadari Kuasa Identitas Anda di dalam Kristus,. Bandung: Lembaga Literatur Baptis, 1997

Armstrong, Thomas. 7 Kinds of Smart, Menemukan dan Meningkatkan Kecerdasan Anda Berdasarkan Teori Multiple Intellingence,. Jakarta: Gramedia Pustaka Utama, 2002

Asmadi, Tengku. Mendidik Anak Tinggi EQ, Ayah Bunda, September 2007

Barbara, De Angelis. Percaya Diri pen. Baty Subakti. Jakarta: PT SUN, 1995

Buletin Achieving True Success: How to Build Character as a Family. International Association of Character Cities, IACC)

Campbell, D. Ross. How to Really Love Your Teenager. Illinois: Victor Books SP, Publications, 1983

Chalke, Steve. Kiat Menjadikan Anak Anda Sukses \& Bahagia . Yogyakarta: ANDI,2009

Daryati, Elia R. Kemandirian Anak, Harian Pikirang Rakyat, 5 Agustus 2007 Pedagagogi dan Psikologi. Haraian Pikiran Rakyat, 5 Agustus 2007

Dobson, James C. Menjadi Orang Tua Bukan untuk Orang-orang Pengecut. . Harvest Publication House: 1996

Gunarsah, Singgih dan Yulia Singgih D. Gunarsah, Psikologi Perkembangan Anak dan Remaja,(Jakarta: BPK Gunung Mulia, 1983.

Gunawan, Adi W. Genius Learning Strategy: Petunjuk Praktis untuk menerapkan Acclerated Learning. Jakarta: Gramedia Pustaka Utama, 2003

Hadiwibowo, Valentino. Gambar diri, Sinar Harapan sore

Heath, Stanley. Kumpulan Makalah Lepas. Bandung: Institut Alkitab Tiranus, 1995

Humble, Wanda. Diktat Kuliah Psikologi Perkembangan. STTII Yogyakarta, 1992

Lase, Jason. Pengaruh Lingkungan Keluarga dan Sekolah terhadap Vandalisme Siswa. Jakarta: Pasca Sarjana UKI, 2005

Motivasi Berprestasi Kecerdasan Emosional, Percaya Diri dan Kinerja,. Jakarta: Program Pasca Sarjana UKU, 2005

Lembaga Alkitab Indonesia Alkitab Edisi Studi 2013

McDowell, Josh \& Bill Jones: Tanya - Jawab Kawula Muda,. Yogyakarta: Yayasan ANDI, 1990

Naat, Dominggus E. Remaja dan Persoalannya, Buletin Gema Anugerah

Patton, Patricia. EQ Kecerdasan Emosional: Membangun Hubungan. Jakarta: Pustaka Delaprasta, 1998 Media, 1998

Pendidikan Agama Kristen: Matakuliah Pengembangan Kepribadian. Jakarta: Depag Bimas Kristen Protestan, 2006

Poerwadarminto, W.J.S. Anggapan, dalam Kamus Umum Bahasa Indonesia. Jakarta: Balai Pustaka, 1982.

Rini, Jacinta F. Percaya Diri, Tien Cyber Indonesiablog. Agustus 2006 
Santrock, John W. Life-Span Development: Perkembangan Masa Hidup, jil. I. Jakarta: Erlangga Publications, 1983

Sasongko, Dhanag . Meningkatkan Minat Belajar, Harian Seputar Indonesia, 21 Februari 2007

Schultz, Duane. PsikologiPertumbuhan: Model-model Kepribadian yang sehat. Yogkarta: Kanisisus, 1991

Soekamto, Soerjono. Remaja dan Masalah-masalahnya: Sebab-musabab dan Pemecahannya.. Jakarta: BPK Gunung Mulia, 1989

Tasmin, Martina Rini. S. Peranan Keluarga dalam Pembentukan Harga Diri,. www.Kepercayaandiri Anak.com

Tim penyusun Kamus Besar Bahasa Indonesia, Percaya dalam Kamus Besar Bahasa Indonesia. Jakarta: Balai Pustaka, 1993 